\title{
The effects of septoplasty on disease-specific and general quality of life: A retrospective longitudinal trial
}

\author{
Septoplastinin hastalık spesifik ve genel yaşam kalitesi üzerine etkileri: \\ Retrospektif longitudinal bir çalışma
}

\author{
Gökçe Şimşek ${ }^{1}$ Bengi Arslan², Burak Erden¹, Nuray Bayar Muluk¹, Rahmi Kılıç \\ ${ }^{1}$ Department of Otolaryngology, Medical Faculty of Kırıkkale University, Kırıkkale, Turkey \\ ${ }^{2}$ Department of Otolaryngology, Gebze State Hospital, Kocaeli, Turkey
}

\begin{abstract}
Objectives: This study aims to evaluate local and general quality of life (QOL) indexes during pre- and postoperative periods in patients who underwent septoplasty procedure.

Patients and Methods: This study is a retrospective review with prospective follow-up performed at a tertiary referral hospital. All patients who were performed septoplasty between January 2011 and January 2012 were identified. Disease-specific QOL was assessed by a Nasal Obstruction Symptom Evaluation (NOSE) questionnaire, and general health status was measured by a 36-item Short Form Health Survey (SF-36). Both of the questionnaires were applied twice in the same visit to measure patients' satisfaction in pre- and postoperative periods.
\end{abstract}

Results: A comparison of pre- and postoperative values after two years did not reveal any significant changes in the eight categories of SF-36 (physical functioning, physical role, bodily pain, general health, emotional role, mental health, social functioning, and vitality). The mean pre- and postoperative NOSE scores were $53.4 \pm 14.5$ and $26.0 \pm 17.8$, respectively $(\mathrm{p}<0.001)$.

Conclusion: According to the results of our study, septoplasty has a significant impact on local symptoms, and markedly improves disease-specific QOL. An evaluation of SF-36 showed that septoplasty has no impact on general health.

Keywords: Nasal septum; NOSE scale; outcome assessment; quality of life, septoplasty; septum deviation; Short Form (36) Health Survey; surgery.

\begin{abstract}
Amaç: Bu çalışmada septoplasti uygulanan hastaların ameliyat öncesi ve sonrası dönemlerinde lokal ve genel yaşam kalitesi (YK) indeksleri değerlendirildi.

Hastalar ve Yöntemler: Bu çalışma, üçüncü basamak bir hastanede yapılan prospektif izlemli retrospektif bir incelemedir. Ocak 2011 ve Ocak 2012 tarihleri arasında septoplasti yapılan tüm hastalar tespit edildi. Hastalığa özgü YK Burun Tikanıklığı Semptom Değerlendirmesi (NOSE) anketi ile değerlendirildi ve genel sağlık durumu 36 maddelik Kısa Form Sağlık Anketi (SF-36) ile ölçüldü. Anketlerin her ikisi de aynı görüşmede hastaların ameliyat öncesi ve sonrası dönemde memnuniyetini ölçmek için iki kez uygulandı.

Bulgular: Ameliyat öncesi ve sonrası değerler iki yıl sonra karşılaştırıldığında, SF-36'nın sekiz kategorisinde (fiziksel fonksiyon, fiziksel rol, vücut ağrısı, genel sağlık, emosyonel rol, mental sağlık, sosyal işlevsellik ve canlılık) anlamlı değişiklik izlenmedi. Ameliyat öncesi ve sonrası ortalama NOSE skorları sırasıyla $53.4 \pm 14.5$ ve $26.0 \pm 17.8$ idi $(\mathrm{p}<0.001)$.

Sonuç: Çalışmamızın sonuçlarına göre, septoplasti lokal semptomlar üzerinde anlamlı etkiye sahiptir ve hastalığa özgü YK’yi belirgin olarak geliştirir. Kısa Form Sağlık Anketi-36 değerlendirmesi, septoplastinin genel sağlık üzerine etkisi olmadığını gösterdi.

Anahtar sözcükler: Nazal septum; NOSE skalası; sonuç değerlendirmesi; yaşam kalitesi; septoplasti; septum deviyasyonu; Kısa Form (36) Sağlık Anketi; cerrahi.
\end{abstract}


Obstructive nasal complaints are among the most common reasons for visits to otorhinolaryngologists. ${ }^{[1]} \mathrm{A}$ common etiology of obstructive symptoms is deviation of the nasal septum, though they can be caused by other conditions including turbinate hypertrophy, adenoid hypertrophy, nasal polyposis, and allergic rhinitis. ${ }^{[2,3]}$ Although not life threatening, obstructive nasal symptoms are associated with considerable disability and are likely to have physiological and social implications for patients. ${ }^{[4]}$ Septoplasty has been generally accepted as the definitive treatment in cases of nasal obstruction due to septal deviation. In the relevant literature, several trials have found that septoplasty is generally beneficial, with a success rate of up to $89 \%$ in the treatment of nasal deviation. ${ }^{[2]}$ However, most were retrospective and only a limited number of trials have addressed the effects of septoplasty on quality of life (QoL) in cases of septal deviation.

The 36-item Short Form Health Survey (SF-36), as a generic instrument of health-related QoL, measures aspects of health important to everyone and thus allows comparisons between different diseases. ${ }^{[5-8]}$ The Nasal Obstruction Symptom Evaluation (NOSE) scale is a disease-specific QoL instrument for use in evaluating nasal obstruction developed in 2010 by Steward et al. ${ }^{[9]}$ The survey is brief and easy to complete, with a minimal respondent burden. It is also reliable and valid, having been used in a number of previous clinical studies. ${ }^{[9,10]}$ In this context, the central purpose of this study was to evaluate the effects of septoplasty on QoL using both generic and symptom-specific QoL instruments.

\section{PATIENTS AND METHODS}

This retrospective longitudinal clinical study was conducted at the Ear, Nose, and Throat Department of Kir1kkale University Faculty of Medicine in a period of one year beginning January 1, 2011 and ending January 1,2012 . The study protocol was approved by the local ethical committee and was conducted in accordance with the basic principles of the Declaration of Helsinki. All participants were given information about the study and agreed to participate in the research.

A total of 107 patients who underwent septoplasty during the study period were identified. Seventy-five patients were excluded based on the following criteria: the patient was younger than 18 years of age $(n=10)$; a concomitant paranasal sinus disease such as chronic sinusitis, allergic rhinitis, or concha bullosa was present $(\mathrm{n}=12)$; sinonasal malignancy was diagnosed $(\mathrm{n}=3)$; nasal valve insufficiency was diagnosed $(\mathrm{n}=10)$; a previous history of septal surgery was present $(\mathrm{n}=15)$; and patients were unavailable or did not want to participate the study $(\mathrm{n}=25)$. A total of 32 patients were eligible and completed this study.

Each patient received two copies of the Turkish version of the NOSE and SF-36 health survey, through which reliable and valid studies were previously conducted within the Turkish population. ${ }^{[11,12]}$ Both questionnaires were applied twice in the same visit and aimed to measure the patients' satisfaction in pre- and postoperative periods.

The SF-36 health survey consists of 36 questions that cover eight health concepts: physical functioning, physical role, bodily pain, general health, emotional role, mental health, social functioning, and vitality. Measures of these health concepts were transformed linearly to a score on a scale of 0 (the worst possible condition) to 100 (the best possible condition).

The NOSE questionnaire is a five-item selfreporting instrument used to assess the severity of symptoms of nasal congestion, nasal obstruction, difficulty breathing, sleep disturbance, and inability to get enough air through the nose during exercise. Each response is assigned a score ranging from 0 (not at all bothered) to 4 (severely bothered), indicating the severity of each symptom.

\section{Statistical analysis}

For the statistical analyses, the SPSS version 15.0 (SPSS Inc., Chicago, IL. USA) software program was used. The values were expressed as a mean \pm standard deviation (SD) whenever appropriate. Categorical variables were reported as number and percent. Normalities of distribution were tested using the Kolmogorov-Smirnov test. Normally distributed variables were compared using a paired sample t-test, whereas non-normally distributed variables were compared using a Wilcoxon Signed-rank test. A value of $p<0.05$ was considered statistically significant.

\section{RESULTS}

The mean age of the patients was $32 \pm 10.1$. The mean time between the surgery and completion of the SF-36 and NOSE surveys was $28.3 \pm 3.3$ ( $\min 24 / \max 36$ months). The comparison of pre- and postoperative generic health quality is presented in Table 1 , according to the results obtained from the current study. None of the categories of the SF-36 showed significant a change before and after the operation. The mean preoperative and postoperative NOSE scores of the subjects were $53.4 \pm 14.5$ and $26.0 \pm 17.8$, respectively. The postoperative decrease in mean NOSE score was statistically significant $(\mathrm{p}<0.001)$ (Table 2$)$. 


\begin{tabular}{|c|c|c|c|c|c|c|c|}
\hline \multicolumn{8}{|c|}{$\begin{array}{c}\text { Table } 1 \\
\text { omparison of pre- and postoperative SF-36 scores of patients }\end{array}$} \\
\hline \multirow[t]{2}{*}{ Parameter } & \multicolumn{3}{|c|}{ Preoperative $(n=32)$} & \multicolumn{3}{|c|}{ Postoperative $(\mathrm{n}=32)$} & \multirow[b]{2}{*}{$p$} \\
\hline & Mean \pm SD & Median & Min.-Max. & Mean \pm SD & Median & Min.-Max. & \\
\hline General health & $18.5 \pm 2.1$ & & & $19.4 \pm 2.5$ & & & 0.123 \\
\hline Physical functioning & $16 \pm 5.2$ & & & $14.5 \pm 4.4$ & & & 0.109 \\
\hline Vitality & $14.5 \pm 1.7$ & & & $14.5 \pm 1.9$ & & & 0.658 \\
\hline Physical role & & 5.5 & $4-8$ & & 5 & $4-8$ & 0.499 \\
\hline Emotional role & & 4 & $3-6$ & & 4 & $3-6$ & 0.636 \\
\hline Social functioning & & 6 & $4-9$ & & 6 & $4-7$ & 0.346 \\
\hline Bodily pain & & 9.5 & $5-11$ & & 9 & $7-11$ & 0.682 \\
\hline Mental health & & 17 & $12-48$ & & 16 & $11-20$ & 0.081 \\
\hline Total score & $92.7 \pm 8.8$ & & & $89.6 \pm 5.3$ & & & 0.54 \\
\hline
\end{tabular}

Because $25 \%$ of the patients were female $(n=8)$ and a 3:1 male predominance was observed, the effect of sex on the change in SF-36 and NOSE values was also investigated. Neither male nor female subjects showed significant differences between the pre- and postoperative SF-36 health surveys. However, the decrease in NOSE scores was found to be statistically significant in both sexes $(\mathrm{p}<0.001)$. The postoperative NOSE values of male and female patients were $27.7 \pm 18.8$ and $21.2 \pm 14.3$, respectively, and the difference was insignificant $(\mathrm{p}=0.384)$.

\section{DISCUSSION}

According to the results of the current study, it can be postulated that septoplasty significantly improves obstructive nasal symptoms and increases diseasespecific QoL. Further, no significant changes were identified within the parameters of the SF-36, which indicated that improvement of local symptoms might not impact general QoL after surgery.

Difficulty in nasal breathing is probably the most common complaint encountered in rhinology practice. Nasal septum deviation is a very common cause of

\section{Table 2}

Comparison of pre- and postoperative nasal obstruction symptom evaluation scores of patients

\begin{tabular}{|lcccc|}
\hline Parameter & $\begin{array}{c}\text { Preoperative } \\
(\mathrm{n}=32)\end{array}$ & & $\begin{array}{c}\text { Postoperative } \\
(\mathrm{n}=32)\end{array}$ & $p$ \\
\cline { 2 - 2 } & $\frac{}{\text { Mean } \pm \mathrm{SD}}$ & & Mean $\pm \mathrm{SD}$ & $P$ \\
NOSE score & $53.4 \pm 14.5$ & & $26.0 \pm 17.8$ & $<0.001$ \\
\hline SD: Standard deviation; NOSE: Nasal obstruction symptom evaluation.
\end{tabular}

nasal obstruction and can significantly reduce QoL by affecting humidification, air filtering, and temperature regulation of the nose. ${ }^{[13]}$ Although septoplasty has been empirically considered the ultimate treatment of septal deviation, the best management of these cases is still under debate. There are no evidence-based guidelines for deciding which patients were suitable for surgery, what kind of operation should be done, or which patients will benefit the most. ${ }^{[14]}$ A QoL assessment may be a good method by which to evaluate treatment effectiveness in patients with septal deviation and to justify septoplasty. However, the reported rates of longterm efficacy vary and the data regarding the effects of septoplasty on patients' QoL are limited.

Previously, Konstantinidis et al. ${ }^{[14]}$ reported that the principal benefits of septal surgery are related to the improvement of nasal symptoms and that general $\mathrm{QoL}$ does not significantly change after the operation. In their recent prospective observational study, Kahveci et al. ${ }^{[11]}$ reported that septoplasty without turbinate reduction yields a marked improvement in the NOSE scores of patients at six months after the operation and concluded that the NOSE scale is a very useful tool for evaluating the effectiveness of pure septoplasty. Similarly, Naraghi et al. ${ }^{[15]}$ found in their prospective interventional study that septoplasty has a profound effect on the general QoL of patients six months after the operation. They used a modified health-related QoL instrument and concluded that the correction of septal deviation not only alleviates the obstructive nasal symptoms but also improves general QoL. In the current study, however, we were able to detect a significant relationship between septoplasty and long-term improvement only in disease specific $\mathrm{QoL}$ on follow-up after a period of two years. 
Several limitations of the study should be acknowledged. The major limitation of the study is that it was a retrospective longitudinal intervention study where the QoL instruments were filled out only during the postoperative period. Furthermore, only a small number of cases were surveyed, and the results were obtained from a single institution.

In conclusion, it is possible to report that septoplasty can result in a significant and long-term amelioration in local nasal symptoms. However, this improvement may not influence the general QoL of patients. To corroborate this, prospective multicenter interventional trials should be performed to investigate the influence of septoplasty on QoL measurements.

\section{Declaration of conflicting interests}

The authors declared no conflicts of interest with respect to the authorship and/or publication of this article.

\section{Funding}

The authors received no financial support for the research and/or authorship of this article.

\section{REFERENCES}

1. Siegel NS, Gliklich RE, Taghizadeh F, Chang Y. Outcomes of septoplasty. Otolaryngol Head Neck Surg 2000;122:228-32.

2. Gandomi B, Bayat A, Kazemei T. Outcomes of septoplasty in young adults: the Nasal Obstruction Septoplasty Effectiveness study. Am J Otolaryngol 2010;31:189-92.

3. Chambers KJ, Sedaghat AR, Roberts DS, Caradonna DS. Nasal obstruction and anosmia. JAMA Otolaryngol Head Neck Surg 2013;139:851-2.

4. Fidan T, Fidan V, Ak M, Sütbeyaz Y. Neuropsychiatric symptoms, quality of sleep and quality of life in patients diagnosed with nasal septal deviation. Kulak Burun Bogaz Ihtis Derg 2011;21:312-17.

5. Baumann I. Quality of life before and after septoplasty and rhinoplasty. GMS Curr Top Otorhinolaryngol Head Neck Surg 2010;9:Doc06.

6. Garratt A, Schmidt L, Mackintosh A, Fitzpatrick R. Quality of life measurement: bibliographic study of patient assessed health outcome measures. BMJ 2002;324:1417-22.

7. Ware JE, Sherbourne CD. The MOS 36-Item Short-Form Health Survey (SF-36). I. Conceptual framework and item selection. Med Care 1992;30:473-83.

8. Soler ZM, Sauer D, Mace J, Smith TL. Impact of mucosal eosinophilia and nasal polyposis on quality-of-life outcomes after sinus surgery. Otolaryngol Head Neck Surg 2010;142:64-71.

9. Stewart MG, Witsell DL, Smith TL, Weaver EM, Yueh B, Hannley MT. Development and validation of the Nasal Obstruction Symptom Evaluation (NOSE) scale. Otolaryngol Head Neck Surg 2004;130:157-63.

10. Gillman GS, Egloff AM, Rivera-Serrano CM. Revision septoplasty: A prospective disease-specific outcome study. Laryngoscope 2014;124:1290-5.

11. Kahveci OK, Miman MC, Yucel A, Yucedag F, Okur E, Altuntas A. The efficiency of Nose Obstruction Symptom Evaluation (NOSE) scale on patients with nasal septal deviation. Auris Nasus Larynx 2012;39:275-9.

12. Cingi C, Eskiizmir G. Deviated nose attenuates the degree of patient satisfaction and quality of life in rhinoplasty: a prospective controlled study. Clin Otolaryngol 2013;38:136-41.

13. Simsek G, Demirtas E. Comparison of surgical outcomes and patient satisfaction after 2 different rhinoplasty techniques. J Craniofac Surg 2014;25:1284-6.

14. Konstantinidis I, Triaridis S, Triaridis A, Karagiannidis $\mathrm{K}$, Kontzoglou G. Long term results following nasal septal surgery. Focus on patients' satisfaction. Auris Nasus Larynx 2005;32:369-74.

15. Naraghi M, Amirzargar B, Meysamie A. Quality of life comparison in common rhinologic surgeries. Allergy Rhinol (Providence) 2012;3:e1-7. 